\title{
BUDAYA ORGANISASI KAMPUS MADANI UIN SUSKA
}

\author{
Oleh : KHAIRUNSYAH PURBA, S.Sos, M.Si
}

\begin{abstract}
ABSTRAK
Sebagai institusi pendidikan yang baru bertransformasi, tentunya UIN SUSKA harus memiliki perhatian yang serius berkaitan dengan budaya organisasi yang akan dikembangkan. Keberagaman latar belakang dosen, mahasiswa yang direkrut dan kesiapan penerimaan perubahan dari anggota lama harus diiringi dengan penguatan budaya organisasi, sehingga perubahan organisasi tidak hanya sebatas perubahan nama tetapi juga menggambarkan semakin baiknya tata kelola dan meningkatnya kemampuan adaptasi organisasi terhadap tantangan yang di dapatkan dari lingkungan organisasi
\end{abstract}

Kata kunci: Organisasi, Budaya Organisasi, Transformasi

\section{A. LATAR BELAKANG}

Perkembangan dan kemajuan sebuah universitas merupakan refleksi kesungguhan ikhtiar dari berbagai elemen civitas akademika yang meliputi universitas tersebut. Kemajuan universitas sebagai organisasi pendidikan tidak hanya dibebankan kepada struktural manajerial universitas, tetapi merupakan beban dan tanggung jawab dosen, guru besar dan mahasiswa sebagai bagian dari komunitasnya. Oleh karena itu dibutuhkan persamaan persepsi terkait output yang dicita-citakan oleh universitas.

Sebagai organisasi pendidikan, universitas merupakan tempat bergantung tegaknya peradapan bangsa dan negara. Oleh karena itu dibutuhkan kesungguhan dalam tata kelola organisasi universitas, sehingga kemajuan peradaban bangsa dapat dirasakan sebagai bagian dari kemajuan ilmu pengetahuan.

UIN SUSKA tumbuh dan berkembang sebagai salah satu institusi pendidikan di Indonesia yang terus berupaya menjawab kebutuhan masyarakat dalam bidang pendidikan. Keseriusan UIN SUSKA untuk memenuhi tuntutan masyarakat di buktikan dengan keberanian melakukan transformasi organisasi, dimana sebelum 4 januari 2005 UIN SUSKA masih berstatus IAIN SUSKA. Transformasi organisasi merupakan adaptasi organisasi terhadap lingkungannya. Begitu juga halnya dengan transformasi UIN SUSKA. Konsekwensi yang tidak bisa dihindarkan dari transfomasi tersebut adalah UIN SUSKA harus membuka jurusan dan fakultas yang umum dan heterogen. Terbukanya jurusan dan fakultas umum ini mengharuskan UIN SUSKA untuk merekrut tenaga pengajar sekaligus mahasiswa sesuai dengan bidangnya.

Keberagaman sumber daya manusia yang direkruit baik dari kalangan mahasiswa dan dosen selayaknya tidak mengurangi, melunturkan bahkan menghilangkan budaya dan nilai-nilai luhur UIN SUSKA sebagai lembaga pendidikan islam. UIN SUSKA sebagai intitusi pendidikan islam memiliki ke khasan dan bahkan nilai lebih dibandingkan universitas lain yang bersifat umum. Oleh sebab itu UIN SUSKA telah mencanangkan program pembelajaran yang diterapkan adalah integrasi ilmu, yakni penyatupaduan ilmu-ilmu umum dengan ilmu agama yang didasarkan dengan Al-Quran dan Sunnah.

Sebagai institusi pendidikan yang baru bertransformasi, tentunya UIN SUSKA 
harus memiliki perhatian yang serius berkaitan dengan budaya organisasi yang akan dikembangkan. Keberagaman latar belakang dosen, mahasiswa yang direkrut dan kesiapan penerimaan perubahan dari anggota lama harus diiringi dengan penguatan budaya organisasi, sehingga perubahan organisasi tidak hanya sebatas perubahan nama tetapi juga menggambarkan semakin baiknya tata kelola dan meningkatnya kemampuan adaptasi organisasi terhadap tantangan yang di dapatkan dari lingkungan organisasi. Stepen Robbin mengungkapkan pentingnya sinergisitas perubahan dengan penguatan budaya organisasi. Budaya organisasi yang lemah mengakibatkan ketidaksiapan individu-individu menghadapi perubahan. Mereka lebih menyukai nilai-nilai, baik nilainilai individu maupun nilai kelompok yang selama ini telah dimiliki. Mereka juga lebih menyukai cara kerja yang selama ini telah mereka lakukan dan menolak adanya perubahan, terutama perubahan yang menuntut kemampuan dan keterampilan baru.

Selain sebagai identitas organisasi, budaya organisasi juga berperan untuk menguatkan standar prilaku dalam pencapai visi dan misi organisasi. Budaya organisasi yang kuat terlihat dari tinggi rasa kepemilikan terhadap organisasi dan sejauh mana setiap individu dalam organisasi memiliki kesamaan persepsi, gerak dalam pencapaian tujuan organisasi.

UIN SUSKA dengan slogan kampus islami madani tentu memiliki ke khasan tersendiri, Untuk mempertahankan kekhasannya, UIN SUSKA menetapkan karakteristiknya sebagai berikut :

1. Pengembangan berbagai cabang ilmu pengetahuan dengan pendekatan religius sehingga nilai-nilai keislaman menjadi ruh bagi setiap cabang ilmu pengetahuan.
2. Pengembangan paradigma ilmu yang memberi penekanan pada rasa iman dan tauhid ( belief Affection )

3. Penyelenggaraan beberapa disiplin ilmu untuk mencapai standar kompetensi ilmu-ilmu keislaman yang memperkuat domain akidah, ibadah, ahlak, dan muammalah islamiah dalam disiplin ilmu sebagai upaya riil mewujudkan integrasi ilmu dengan islam

4. Pembinaan dan pengembangan lingkungan yang madani sesuai dengan nilai-nilai islam.

5. Perwujudan keunggulan akademik dan profesionalisme yang didasarkan pada moral keagamaan dalam kehidupan kampus di kalangan sivitas akademika.

6. Mengembangkan Studi Regional Islam Asia Tenggara dan Tamaddun Melayu sebagai pola ilmiah pokok.

Kesuksesan pencapaian karakteristik yang ditetapkan bukanlah hal yang mudah. Diperlukan penerapan kebijakan-kebijakan sekaligus penguatan budaya organisasi pada lapisan anggota organisasi. Tidak hanya pada level pimpinan universitas dan fakultas tetapi juga mencakup seluruh pegawai, seluruh dosen dan mahasiswa. Namun berdasarkan pengamatan penulis masih sangat sedikit dokumen dan kebijakan yang menjelaskan, menggambarkan dan menguatkan nilai dan budaya organisasi UIN SUSKA Riau. Tentu hal ini akan sangat menyulitkan untuk membentuk keseragaman budaya kampus islami madani yang tercermin dalam aktivitas dan kerja setiap anggota organisasi.

Karakteristik output yang akan dibuat, perlu didudukkan bersama sehingga ada keseragaman atau kesamaan identitas walau dari heterogenitas bidang pengetahun. Sebagai institusi yang mengembangkan kampus islami madani tentu nilai lebih yang dimiliki UIN SUSKA adalah karakteristik 
mahasiswa yang dekat dengan nilai-nilai akademis sekaligus nilai religius. Perangkat pembentukan nilai-nilai religius masih dirasa kurang, diantara yang menonjol adalah belum terbangunnya mesjid UIN SUSKA sebagai sentral peningkatan nilai-nilai religius.

Berdasarkan kenyataan tersebut penulis ingin mengetahui lebih dalam budaya organisasi kampus madani UIN SUSKA Riau

\section{B. PERUmuSan masalah}

UIN SUSKA sebagai Perguruan Tinggi Agama Islam telah melakukan perubahan secara institusi dari IAIN SUSKA sejak tahun 2005. Transformasi atau perubahan tersebut perlu dikaji, apakah prosesnya disertai dengan penguatan budaya organisasi, sehingga dapat diketahui apakah budaya yang berlaku hingga saat ini masih menggunakan pola-pola lama dan bersifat statis yang dapat menghambat proses adaptasi organisasi terhadap lingkungannya atau budaya organisasi yang membantu adaptasi UIN SUSKA terhadap lingkungannya. Berdasarkan keterangan diatas maka penulis merumuskan masalah : Bagaimanakah budaya organisasi kampus madani UIN SUSKA Riau.

\section{TUJUAN PENELITIAN}

Penelitian ini bertujuan untuk mengetahui sejauh mana penerapan budaya organisasi kampus madani UIN SUSKA RIAU .

\section{RUANG LINGKUP PENULISAN}

Penelitian ini dilakukan dilakukan di Universitas Islam Sultan Syarif Kasim Riau dengan memanfaatkan dokumentasi berupa referensi dan penelitian sebelumnya yang berkaitan dengan objek penelitian dan observasi terhadap fenomena-fenomena yang berkembang terkait dengan budaya organisasi kampus madani UIN SUSKA. Hal yang patut disadari bahwa kesuksesan perubahan atau transformasi bergantung dengan prilaku dan budaya yang didesain oleh organisasi, sehingga setiap anggota organisasi mencerminkan gerak dan aktivitasnya sesuai dengan budaya dan prilaku yang didisain oleh budaya

\section{E. KERANGKA TEORI}

\section{Budaya Organisasi}

Gibson, dkk (1996:76) mengungkapkan budaya itu mengandung pola eksplisit dan implisit dari dan untuk prilaku yang dibutuhkan serta diwujudkan dalan simbol yang menunjukkan hasil kelompok manusia yang berbeda. Budaya organisasi merupakan faktor penentu dalam pencapai tujuan-tujuan yang telah ditetapkan oleh organisasi. Keefektipan tata kelola dan proses transpormasi sangat bergantung sejauh mana budaya organisasi di desain dan diterapkan oleh anggota-anggota organisasi.

Stephen P. Robbin ( 1996;479), mengungkapkan budaya organisasi merupakan nilai-nilai dominan yang didukung oleh organisasi, falsafah yang menuntun kebijaksanaan organisasi terhadap pegawai dan pelanggan, cara suatu pekerjaan dilakukan, asumsi dan kepercayaan dasar yang terdapat diantara anggota organisasi. Kultur Organisasi merupakan kesepakatan bersama tentang nilai yang dianut bersama dalam kehidupan organisasi dan mengikat semua orang dalam organisasi bersangkutan. Dengan demikian orang-orang yang ada didalam organisasi berinteraksi dan beraktivitas dengan pola yang teratur

Sedangkan Trice, Beyer mengatakan kultur oraganisasi mewakili sebuah pola kompleks berupa keyakinan, espektasi- 
espektasi, ide-ide, nilai-nilai, sikap dan prilaku yang diyakini dan dirasakan oleh para anggota suatu organisasi.

Schein,1985, kultur keorganisasian mencakup hal-hal berikut :

1. Prilaku rutin, yang terjaadi sewaktu orang berinteraksi seperti : ritual-ritual keorganisasian, seremoni-seremoni dan bahasa yang umumnya digunakan.

2. Norma-norma yang dianut oleh kelompok-kelompok kerja pada seluruh organisasi yang bersangkutan seperti upah layak untuk pekerjaan yang dilaksanakan

3. Nilai-nilai dominan yang dianut oleh suatu organisasi seperti, misalnya kwalitas produk

4. falsafah yang mengarahkan kebijakan kebijakan suatu organisasi terhadap karyawan dan para pelanggan.

5. Peraturan-peraturan permaian, untuk melaksanakan tata pergaulan di dalam organisasi yang bersangkutan, atau tata cara yang perlu dipahami dan dipelajari oleh karyawan baru, agar ia diterima oleh para anggota lainnya dalam organisasi.

6. Perasaan atau iklim yang timbul di dalam sebuah organisasi oleh karena tata susunan fisikalnya, dan cara denaga apa para anggota organisasi tersebut berinteraksi dengan pelanggan atau dengan pihak lainnya

Budaya mengimplikasikan adanya karakteristik tertentu dalam organisasi. Karakteristik tersebut menjadi gambaran kebiasaan yang terjadi dalam keseharian organisasi. Budaya organisasi yang kuat dapat dilihat dari nilai-nilai dasar yang dianut kuat, diatur dengan baik dan dirsakan bersama oleh anggota organisasi. Semakin banyak anggota organisasi yang menerima dan merasa terikat dengannya maka semakin kuat budaya tersebut dan semakin tinggi tingkat efektifitas organisasi. Efektifitas organisasi akan semakin membuat mudah organisasi mencapai tujuan-tujuannya
Budaya organisasi merupakan pola keyakinan dan nilai-nilai dalam organisasi yang dipahami, dijiwai dan dipraktekan oleh anggota organisasinya sehingga pola tersebut memberikan makna tersendiri bagi organisasi yang bersangkutan dan menjadi dasar aturan berperilaku (Sobirin, 2005). Hal ini berarti setiap organisasi mempunyai sistem makna yang berbeda. Perbedaan ini menyebabkan setiap organisasi mempunyai karakteristik yang unik dan berbeda serta respon yang berbeda ketika menghadapi masalah yang sama. Disamping

itu perbedaan sistem makna ini dapat menyebabkan perbedaan perilaku para anggota organisasi dan perilaku organisasi itu sendiri. Akar perbedaan ini bersumber pada asumsiasumsi dasar yang meliputi keyakinan, nilai-nilai, filosofi atau ideologi organisasi yang digunakan dalam memecahkan persoalan organisasi.

Bebarapa Karakteristik Budaya Organisasi. Menurut Robin,(2003) karakteristik budaya organisasi digambarkan dengan hal-hal sebagai berikut :

(1) Innovasi dan keberanian mengambil resiko, yaitu sejauhmana organisasi mendorong anggota organisasi untuk bersikap inovatif dan berani mengambil resiko serta bagaimana organisasi menghargai tindakan pengambilan resiko oleh anggota organisasi dan membangkitkan ide bagi individu dalam organisasi.

(2) Perhatian terhadap detail, yaitu sejauh mana organisasi mengharapkan anggota organisasi (pegawai) memperlihatkan kecermatan, analisis dan perhatian terhadap rincian.

(3) Berorientasi pada hasil, yaitu sejauhmana manajemen memusatkan perhatian pada hasil dibandingkan perhatian terhadap tekhnik dan proses yang digunakan untuk meraih hasil tersebut. 
(4) Berorientasi pada manusia, yaitu sejauhmana keputusan manajemen memperhitungkan efek hasil-hasil pada orang-orang di dalam organisasi.

(5) berorientasi pada tim, yaitu sejauhmana penekanan diberikan pada kerja tim dibandingkan dengan kerja indivdual.

(6) Agresivitas, yaitu sejauhmana orangorang dalam organisasi itu agresif dan kompetitif untuk menjalankan budaya organisasi sebaik-baiknya.

(7) Stabilitas yaitu sejauh mana kegiatan organisasi menekankan status quo sebagai kontras dari pertumbuhan.

Budaya Organisasi memiliki peran yang cukup signifikan bagi organisasi tersebut. setidaknya ada tiga peranan penting budaya organisasi, yaitu

a. memberikan identitas bagi
anggotanya
b. meningkatkan komitmen terhadap visi
dan misi organisasi
c. Memperkuat standar perilaku.
Ketika budaya organisasi melekat kuat, maka masing-masing anggota akan merasa bahwa mereka adalah bagian dari organisasi. Perasaan sebagai bagian dari organisasi akan memperkuat komitmennya terhadap visi dan misi organisasi.

Budaya juga akan mengarahkan perilaku anggota organisasi. Budaya organisasi memberikan banyak pengaruh kepada individu dan proses organisasi. Budaya memberikan tekanan pada individu untuk bertindak ke arah tertentu, berfikir serta bertindak dengan cara yang konsisten dengan budaya organisasinya. Tidak ada satupun tipe budaya organisasi yang terbaik yang dapat berlaku universal. Yang terpenting adalah organisasi harus mengetahui potret budaya organisasi saat ini dan mengevaluasinya apakah budaya yang berlaku tersebut dapat mendukung program perubahan organisasi. Untuk membangun budaya organisasi yang dapat mendukung perubahan organisasi dibutuhkan alat. Alat utamanya adalah komunikasi yang efektif yaitu komunikasi yang sifatnya

segala arah tidak hanya dari atas ke bawah saja, sehingga akan memperlancar usaha pembangunan budaya organisasi yang baru. Dengan komunikasi yang efektif, organisasi dapat mengkomunikasikan pentingnya perubahan, menampung saran dan masukan dari anggota organisasi dan hubungan antar anggota organisasi serta meningkatkan keterlibatan anggota organisasi. Tingginya keterlibatan anggota organisasi akan menjamin suksesnya upaya membangun budaya organisasi yang baru sehingga dapat mendukung perubahan organisasi.

\section{Kampus Madani}

Istilah Madani dalam kamus bahasa arab karangan Prof. Mahmud yunus memiliki arti orang kota, orang sipil. Madani berasal dari bahasa arab, maddana, yatamaddanu, mutamaddinun. Istilah kampus madani merupakan slogan yang dipakai oleh UIN SUSKA.

Ada beberapa karakteristik dari komunitas madani yang diungkapkan oleh Bahmueller (1997), diantaranya;

a. Terintegrasinya individu-individu dan kelompok-kelompok ekslusif kedalam masyarakat/ organisasi melalui kontrak sosial dan aliansi sosial.

b. Menyebarnya kekuasaan sehingga kepentingan-kepentingan yang mendominasi dalam masyarakat/organisasi dapat dikurangi oleh kekuatan alternatif

c. Dilengakapinya program-program pembangunan yang berbasis kepentingan masyarakat/anggota organisasi

d. Terjembataninya kepentingankepentingan individu dan organisasi karena keanggotaan organisasi voluntir mampu masukan-masukan 
terhadap keputusan-keputusan pimpinan eksekutif

e. Tumbuhkembangnya kreatifitas

f. Meluasnya loyalitas (kesetiaan) dan trust (kepercayaan) sehingga setiap individu mengakui keterkaitannya dengan anggota organisasi lain dan tidak mementingkan diri sendiri.

g. Adanya pembebasan masyarakat melalui kegiatan lembaga-lembaga sosial dengan berbagai ragam perspektif.

Dari uraian ciri tersebut mengindikasikan bahwa kampus madani merupakan organisasi yang setiap anggotanya menyadari akan hak-hak dan kewajibannya dalam menyuarakan dan mewujudkan kepentingannya. Disisi lain organisasi memberikan ruang yang luas bagi berkembangnya kreatifitas anggota organisasi yang ditujukan untuk kepentingan kemajuan organisasi. Kesetiaan dan kepercayaan pada pimpinan eksekutif organisasi memberikan peluang untuk terciptanya iklim organisasi yang kondusif sehingga perubahan organisasi memberikan efek terciptanya prestasi organisasi.

Namun demikian menghadirkan komunitas madani dalam organisasi kampus bukanlah hal yang mudah, tetapi melalui proses yang panjang. Proses tersebut juga merupakan bagian adaftasi organisasi terhadap lingkungan internal dan eksternal. Ada beberapa persyaratan yang harus dipenuhi untuk terpenuhinya komunitas madani dalam organisasi, yaitu

a. Terpenuhinya kebutuhan dasar individu, keluarga dan kelompok dalam organisasi

b. Berkembangnya human capital (modal manusia) dan Social Kapital (modal sosial) yang kondusif bagi terbentuknya kemampuan melaksanakan tugas-tugas kehidupan dan terjalin nya kepercayaan dan relasi sosial antar kelompok. c. Tidak adanya diskriminasi dalam berbagai bidang, dengan kata lain terbukanya akses terhadap pelayan sosial

d. Adanya hak, kemampuan dan kesempatan bagi masyarakat dan lembaga-lembaga yang untuk terlibat dalam berbagai forum, dimana isu-isu bersama dapat dikembangkan.

e. Adanya kohesifitas antar kelompok dalam organisasi serta tumbuhnya sikap saling menghargai.

f. Terselenggaranya kehidupan organisasi yang memungkinkan lembaga-lembaga yang didalamnya dapat berjalan dan berkembang secara produktif dan berkeadilan sosial

g. Adanya jaminan, kepastian dan kepercayaan antara elemen-elemen organisasi yang memungkinkan terjalinnya hubungan dan komunikasi antar mereka secara teratur dan terbuka.

\section{F. METODOLOGI}

\section{Tehnik Pengumpulan Data}

Tehnik pengumpulan data yang dipergunakan dalam penelitian ini guna memperoleh data adalah sebagai berikut:

a. Observasi

Yaitu tehnik pengumpulan data melalui pengamatan langsung ke lapangan untuk mengidentifikasi situasi dan kondisi objek penelitian, yaitu khususnya mengenai budaya organisasi Universitas Islam Negeri Sultan Syarif Kasim Riau.

b. Tehnik dokumentasi

Yaitu mencari data mengenai hal-hal tertentu atau variabel yang berupa catatan, artikel, buku, surat kabar, majalah , internet, hasilhasil penelitian sebelumnya dan sebagainya yang isinya terdiri dari penjelasan dan pemikiran terhadap peristiwa-peristiwa terkait.

\section{Tehnik Analisis Data}


Penelitian ini memberikan gambaran keadaan berdasarkan fakta yang tampak, oleh kaena itu data akan dianalisa secara deskriptif. Penelitian deskriptif dimaksudkan untuk mendeskripsikan data penelitian sesuai dengan variabel-variabel yang akan diteliti tanpa melakukan pengujian hipotesis, karena dalam penelitian ini penulis tidak membuat hipotesis. Disamping melakukan analisis, hasil penelitian akan diterjemahkan, dan diuraikan secara kualitatif sehingga diperoleh gambaran mengenai situasi-situasi atau peristiwa-peristiwa yang terjadi di lapangan.

\section{F. PEMBAHASAN}

Budaya organisasi merupakan nilainilai dominan yang didukung oleh organisasi, falsafah yang menuntun kebijaksanaan organisasi terhadap anggota dan pelanggan, cara suatu pekerjaan dilakukan, asumsi dan kepercayaan dasar yang terdapat diantara anggota organisasi. Membangun budaya organisasi tidaklah semudah mengucapkannya, harus melewati suatu proses yang lama dan berkelanjutan. Di katakan berkelanjutan karena nilai dan norma yang berkembang dalam budaya tersebut senatiasa mengalami perubahan sesuai dengan kebutuhan organisasi dan perkembangan zaman.

Universitas Islam Sultan Syarif Kasim Riau sebagai organisasi publik yang telah mengalami perubahan secara institusi, memantapkan slogan universitas sebagai kampus islami madani. Dengan karekteristik dan kekhasaan yang dimilikinya UIN SUSKA mencanangkan World Class University. Penulis mengamati budaya organisasi UIN SUSKA Riau melalui karakteristik dan di adapatasikan kembali indikator-indikatornya dengan situasi penelitian. Bebarapa budaya organisasi yang menonjol untuk diamati di UIN SUSKA diantaranya, integrasi ilmu dan pembinaan keimanan, pembinaan dan pengembangan nilai-nilai madani sesuai dengan nilai keislaman, perwujudan keunggulan akademik dan profesionalisme

Dengan berupaya menerapkan integrasi ilmu UIN SUSKA memiliki nilai lebih dibandingkan dengan kampus-kampus umum lainnya. Beberapa tantangan yang tidak dapat dipungkiri adalah kejelasan konsep integrasi ilmu yang ada di UIN SUSKA Riau. Konsep integrasi ilmu harus jelas dan tersosialisasikan oleh seluruh kalangan terutama dosen sebagai tenaga pengajar. Kejelasan konsep integrasi ilmu akan menegas bagaimana output yang akan dihasilkan UIN SUSKA Riau. Hingga saat ini UIN SUSKA memiliki 4 fakultas umum yaitu Fakultas Ekonomi, Fakultas Sain Teknologi, Fakultas Pikologi dan Fakultas Pertanian dan Peternakan. Dosen fakultasfakultas umum tersebut dominan berlatar belakang umum. Dengan demikian perlu penguatan pemahaman dan kajian keagamaan yang dikaitkan dengan bidang-bidang umum. Bentuk kajian yang lainnya bisa dikonversikan dengan penelitian integrasi ilmu. Namun hingga saat ini penguatan dan program untuk keagamaan hanyalah kajian jumat yang pada umumnya pesertanya hanyalah kalangan pegawai. Hal lain yang sangat terasa adalah belum tersedianya mesjid sebagai pusat pendidikan dan ibadah bagi civitas akademika UIN SUSKA. Untuk menguatkan nilai-nilai atau budaya tersebut tentu sangat dibutuhkan perangkat yang dapat menjaga keberlangsungan budaya organisasi, sehingga budaya organisasi tidak hanya dipahami para pimpinan organisasi, tetapi juga dipahami dan dijalankan seluruh anggota organisasi. Untuk keperluan tersebut UIN Suska telah membuat kebijakan Kode Etik UIN Suska untuk kalangan pimpinan, pegawai dan mahasiswa. Hal ini di dukung dari pernyataan Rektor UIN Suska.

Budaya organisasi seharusnya dijadikan acuan bagi setiap orang dalam organisasi untuk bertindak, bertingkah laku dan bekerja. Dengan demikian yang tidak 
kalah penting adalah sinergisitas antara budaya UIN Suska dengan kebijakan dan program-program kerja yang dibuat untuk setiap level manajemen, baik di tingkat universitas, di tingkat fakultas maupun di tingkat jurusan.

\section{G. KESIMPULAN DAN SARAN Kesimpulan}

Setelah mencermati kondisi budaya organisasi dalam transformasi atau perubahan Universitas Islam Sultan Syarif Kasim Riau, penulis mencoba menyimpulkan bahwa budaya organisasi di Universitas Islam Sultan Syarif Kasim Riau masih cenderung formalitas. Kode etik untuk pegawai, dosen dan mahasiswa memang telah terdokumentasi, namun hal ini perlu disosialisasikan kesuluruh level manajemen dan kalangan anggota organisasi, sehingga setiap anggota organisasi memiliki konsep dan pemahaman yang sama tentang cara bertindak, bertingkak laku dan bekerja dalam organisasi.

Evaluasi pelaksanaan dan pencapai budaya organisasi belum maksimal. Evaluasi sangat dibutuhkan agar diketahui sejauh mana efektifitas budaya organisasi berjalan pada setiap anggota organisasi. Hal ini juga dimaksudkan agar dapat disinergisan antara budaya organisasi dengan aktivitas dan prilaku pegawai, dosen dan mahasiswa. Budaya organisasi adalah nilai-nilai dan kebiasaan yang diakui dilaksanakan secara bersama-sama demi mencapai tujuan organisasi. Di Universitas Islam Negeri Sultan Syarif Kasim Riau masih banyak pelanggaran berkaitan dengan kode etik tersebut, terutama kode etik yang berkaitan dengan mahasiswa.

Program penguatan budaya organisasi yang dibuat juga belum dirasa optimal dimana tidak semua anggota organisasi terlibat didalamnya, hal ini dapat diketahui jarangnya dosen mengikuti mengikuti kajian jumat yang setiap minggunya diadakan.

\section{Saran}

$\begin{array}{cc}\text { Perubahan organisasi } & \text { bukanlah } \\ \text { semata-mata perubahan fisik (gedung- }\end{array}$ gedung) atau perubahan status semata. perubahan organisasi diawali dan disertai dengan perubahan nilai-nilai, norma dan prilaku yang menjadi panutan dan pedoman bagi seluruh anggota organisasi. Nilai, norma dan prilaku yang ditetapkan akan membantu anggota organisasi untuk bertindak dan bersikap sesuai dengan kekhasan organisasi tersebut, sehingga segala tindakan dan prilaku anggota organisasi mendukung tercapainya visi Universitas Islam Sultan Syarif Kasim.

Universitas Islam Negeri Sultan Syarif Kasim Riau memang telah memiliki kode etik untuk pimpinan, pegawai dosen dan mahasiswa, tetapi penulis menganalisa kode etik tersebut masih bersifat umum dan tidak menggambarkan tentang kekhassan Universitas Islam Negeri Sultan Syarif Kasim Riau. Alangkah baiknya bila kode etik tersebut lebih spesifik dan komprehensif.

Adapun untuk kode etik mahasiswa, masih banyak pelanggaran yang dilakukan. Padahal hal tersebut telah tertulis dalam kode etik mahasiswa, diantaranya adalah cara berbusana yang transparan dan membentuk tubuh, potongan rambut mahasiswa pria yang panjang, berboncengan antara mahasiswa dan mahaiiswi yang bukan mahram. Seandainya hal tersebut terasa masih berat untuk direalisasikan ada baiknya pihak Universitas Islam Negeri Syarif Kasim Riau menyediakan prasarana yang dapat memahamkan mahasiswa tentang hakikat peraturan tersebut.

Selain itu harus ada tindakan dan hukuman yang tegas terhadap pelanggaran kode etik untuk setiap elemen organisasi. 
Dikalangan pegawai dan akademisi budaya organisasi harus didukung dengan dokumen tertulis yang menggambarkan bagaimana seharusnya anggota organisasi bertindak, bersikap dan berprilaku.

\section{H. DAFTAR PUSTAKA}

Berger, Lance A.; Sikora, Martin J.; \& Berger, Dorothy R. 1994. The Change Management Handbook: a road map to corporate transformation. Chicago: Irwin.

Gibson, James L, Ivancevich, John M, Donnelly, James R Organisasi, Jakarta, Erlangga

Kasali, Rhenald, Change !, Jakarta , PT. Gramedia Pustaka Utama

Keputusan Menteri Agama RI no 16 Tahun 2003 tentang Statuta Institut Agama Islam Negeri Sultan Syarif Kasim Riau.

Kotter, Jhon P, 1999, Kepemimpinan dan Perubahan, Jakarta, PT. Gelora Aksara Pratama

Osborne, David . Plastrik, Peter, 2001, Memangkas birokrasi, lima strategi menuju pemerintahan wirausaha. Jakarta, PPM, Teruna Grafika.
Robbin, Stephen, 1996, Teori organisasi, struktur, desain dan aplikasi, Jakarta, penerbit arcan

Siagian, P. Sondang, 2007, Teori Pengembangan Organisasi, Jakarta ; Bumi Akasara

Sobirin, Ahmad, 2007, Budaya Organisasi, Yogyakarta, Sekolah Tinggi Ilmu Manajemen

Susanto, A.B, dkk, 2006, Strategi Organisasi, Yogyakarta, Amara Books

Wibowo, 2005, Manajemen Perubahan, Jakarta, Rajawali Press

Wibowo, 2006, Managing Change, Pengantar manajemen perubahan, Bandung, Alfabeta

Winardi, J, 2004, Manajemen Prilaku Organisasi , Jakarta, Kencana Prenada Media Group. 